David Roediger (University of Minnesota) closed the discussion and, in many ways, pulled together the dual focus on the scholarly applications and political applications of class in multicultural society. He started by talking about a recent USA Today article that had stated that the majority of organized workers in the United States were no longer either white or male, and he illustrated this fact by recounting a vacation trip to Las Vegas during which the Hotel and Restaurant Employees Union (HERE), a union in which women and people of color form a large majority of the rank and file, were conducting an organizing drive. He asked, "Can we return to class as an organizing tool?" He cautioned that in "getting back to class, we have to realize what we're getting back to." Using the work of Alexander Saxton on white workers in the western United States, he explored the pitfalls of using concepts of class based on the assumption that workers are white and male. Roediger concluded that, as labor historians, we have progressed in writing inclusive working-class histories but are also writing amidst a chorus of apprehension that labor history is in decline. Roediger rejected, in qualitative terms, the decline of labor history. $\mathrm{He}$ cautioned, however, that its acceptance in the broader field of US History should not be complacently presumed. The discussion that followed ranged broadly but clustered around competing historical interpretations of class, race, and gender and how multiculturalism fits into building a new labor movement.

The session on the uses of class in a multicultural age at the $\mathrm{OAH}$ conference generated many more questions than answers on its central issues. It did, however, reveal a vitality and a level of interest which reassured those of us who were concerned by the small number of labor and working-class history sessions at the conference and by the weak attendance at some of those sessions. This session's greatest value, perhaps, was in the consistent crossing of borders between class-as-an-analytical-tool and class-as-a-transformative-agent: Today, race, gender, and citizenship have tremendously complicated both applications.

\title{
A National Association for Working-Class History
}

\author{
James R. Barrett
}

University of Illinois at Urbana-Champaign

Several developments have converged recently to produce the first serious discussion of establishing a national organization of scholars, activists, and others concerned with advancing the study of working-class history in the United States. Among these are the "crisis" in labor history, however real 
or imagined; a desire to better integrate working-class history with efforts to reinvigorate the labor movement; and efforts to strengthen the journal Labor History and the field in general.

The "crisis" discussion has, of course, been going on for years; the virtue of this past year's conversation, which took place publicly on $\mathrm{H}$ Labor (the labor history Internet discussion list) and more recently at the North American Labor History conference in Detroit, was its focused quality. Those who took part asked some probing, straightforward questions and even advanced possible solutions to the problems many have observed in the field. Members of the Labor History editorial board had launched the discussion in the Fall of 1996 by asking readers for their suggestions about how to invigorate the journal; most respondents preferred to discuss the health of the field as a whole. During the discussion, H-Labor's editor, Seth Widgerson (University of Maine at Augusta) mentioned the idea of a national organization and Roger Horowitz (Hagley Museum) responded by proposing the formation of an "Association for Working-Class History." Its main objectives might be "(1) creating strong links among historians who study the working class; (2) stimulating consideration of class issues in other branches of history; (3) encouraging links between academic historians and the union movement."

In April 1997 a group assembled at the Organization of American Historians conference to continue the discussion. This gathering, which took place in a very pretentious San Francisco restaurant over the most expensive breakfast I have ever consumed, involved about a dozen people, all well-intentioned but none claiming to be in any sense representative of anything.

We started with the observation that, because the discipline has changed enormously over the past decade, we should aim to draw in the diverse group of colleagues who define working-class history very broadly and particularly young people who best represent new and different approaches and, thus, future scholarship. Everyone agreed that some sort of national organization could be useful in the ways that Horowitz and others had suggested in the Fall 1996 discussion. There was also broad agreement on the idea of the organization being inclusive in the sense of involving and even helping local, state, regional, and union groups. In fact, many of these groups are so successful that the new body could not hope to "compete" with them if it wanted to. We also considered overthrowing the wage labor system, but decided to settle for a scholarly approach. Several of us had had experience with the ongoing labor teach-in movement, which represents another promising field for the efforts of any new labor history organization. (See "The Fight for America's Future: A Teach-In with the Labor Movement," ILWCH 52 [Fall 1997], 146-51.)

The group also agreed to solicit ideas from colleagues regarding a name for the organization, its scope, and other practical suggestions for moving on the idea. Seth Widgerson generously agreed to continue to field 
and post suggestions on H-Labor. We also planned to continue the discussion and some of the organizing it required at the North American Labor History Conference (NALHC) in Detroit in October 1997. Liz Faue (Wayne State University), the NAHLC's coordinator, placed two sessions on the program to facilitate this: an evening plenary on the state of the field, and an extended lunch to work out some of the details of the proposed association.

About 250 scholars and other interested folks from around the United States and abroad gathered at the NALHC on October 23-25, 1997 and resumed the discussion in earnest. Initial prospects for a national labor history association looked rather gloomy given a high degree of skepticism and a wide range of opinions on the subject, but the results by the end of the conference were rather more promising. Oddly, perhaps, most presenters at the first night's plenary session on "New Directions in Labor History and the Labor History Association" focused on reasons (some of them quite persuasive) for why such a body should not be formed, though none of them argued strongly for such a course.

Nelson Lichtenstein (University of Virginia) thought, as did Alice Kessler-Harris (Rutgers University), that labor history was already very influential within the discipline and especially in US history. Lichtenstein came around to acknowledging that such an organization might be worth the effort, in part to support - perhaps to influence-the new leadership of the AFL-CIO. Peter Rachleff (Macalester College) was concerned that the association would draw time and energy away from scholars' engagement with the labor movement, and cautioned against mistaking professional pursuits for labor activism. Kessler-Harris noted that a national association might be exclusionary in conceptual terms, in effect defining some of the most interesting recent work out of the field entirely. Kim Phillips (College of William and Mary) warned that any association ran the risk of being exclusionary in social terms, since the NALHC and similar gatherings include few people of color. Nancy Quam-Wickham (University of California, Berkeley) was more sympathetic to the idea of the association, and hoped that it would be able to support local initiatives, foster contact with regional labor studies groups, and address issues relating to the corporatization of the university.

By the end of the plenary session, things did not look too promising. Informal discussion continued through the weekend, generating a certain amount of tension but also a number of ideas about how the whole group might be able to move ahead. At the very least, there was a feeling that significant questions hung in the balance. Two different constitutions appeared, one drafted in advance by Roger Horowitz on the basis of $\mathbf{H}$ Labor discussions and the other by John Bukowczyk (Wayne State University) on the basis of early discussions at the conference.

The mood seemed to have shifted considerably by Saturday morning, which featured small workshops to discuss specific organizational prob- 
lems. (While there were undoubtedly deeper forces at work, I would attribute at least part of the change to the Friday evening entertainment at Alvin's Twilight Bar and Deli, which managed to loosen up this rather grim group of labor historians.) The workshops reported back at a lunchtime organizational meeting, which provisionally adopted the name WorkingClass and Labor History Association and declined to adopt either constitution, opting instead to form an organizing committee-a designation with considerable resonance for labor historians. This committee was charged with drafting a constitution, fostering contacts with regional and local labor history and labor studies bodies, developing panels for the NALHC and possibly for other conferences, and presenting a slate of candidates for the election of a permanent organizing committee at the next NALHC in October 1998.

There was concern to create a committee that was broadly inclusive in terms of race, gender, and ethnicity and that represented regional and local associations with large labor memberships, as well as scholars from all regions of the United States. (In this regard, colleagues who can further the goals of inclusion by joining the committee are urged to volunteer.) The organizational meeting accepted the Wayne State University History Department's kind offer, tendered by its chair, Marc Kruman, to serve as headquarters for the new association.

The organization committee elected Julie Greene (University of Colorado) and Liz Faue as co-conveners, and constituted three committees: constitution, program, and outreach. A new draft constitution is already circulating on H-Labor, which seems destined to become the group's electronic arm. Those interested in the Working-Class and Labor History Association may contact the group at the Department of History, Wayne State University, 3094 Faculty/Admin Building, Detroit, MI, 48202, USA or electronically on H-Labor at H-LABOR@h-net.msu.edu. 